\title{
Promoting International Education for Indigenous Elementary Schools in Taiwan: School Principals' Perspectives
}

\author{
Shan-Hua Chen ${ }^{1}$ \\ ${ }^{1}$ Graduate Institute of Educational Administration and Policy Development, National Chiayi University, Taiwan \\ Correspondence: Shan-Hua Chen, Graduate Institute of Educational Administration and Policy Development, \\ National Chiayi University, Taiwan. E-mail: shanhua@mail.ncyu.edu.tw
}

Received: June 28, 2014 Accepted: August 9, 2014 Online Published: April 2, 2015

doi:10.5539/ass.v11n9p21 URL: http://dx.doi.org/10.5539/ass.v11n9p21

\begin{abstract}
Globalization has led governments to promote international education to strengthen students' cultural integration and international perspective. To boost social equity and justice, Taiwan's government focuses international education efforts on indigenous schools to promote indigenous students' competitiveness. This research explored the significance of international education in different hierarchies (students, schools, ethnicities, and societal levels) to identify the relative goals and comparative relationships of different aspects of international education. What effect does this international education policy have and how is its importance weighted toward different levels? Using the analytic hierarchy process, questionnaires were administered to elementary school principals, and level weights were used to determine the relative weights of the purposes of international education. The correspondence analysis (CA) also explored the relationship between the purposes and strategies of international education. Finally, suggestions for schools' practices in international education are offered.
\end{abstract}

Keywords: international education, analytic hierarchy process (AHP), correspondence analysis (CA), Taiwan

\section{Introduction}

Globalization leads to close contact among countries, significantly influencing people's lives. As a result, nations' educational strategies have become concerned with countries' human development and competition, ultimately prioritizing the promotion of educational internationalization strategies that extend even to primary schools (Lin \& Chen, 2013).

In 2011, "A White Paper on International Education for Primary \& Secondary Schools" highlighted the Taiwan government's determination to promote international education and cultivate students' diverse visions and competencies. These goals also universally applied to indigenous students. Indigenous people account for only 5\% of the global population and are distributed across various countries; they generally face a disadvantage in terms of economic and social status. Taiwan's aboriginals are no exception. Minorities in Taiwan also similarly face a disadvantage. The United Nations has provided information about international indigenous peoples so that students can learn about other nations' experience of development, such as how to help the vulnerable overcome the obstacles within their own country through internationalization (UNESCO, 2014). The international rules include "United Nations' Principles and Guidelines for the Protection of the Heritage of Indigenous Peoples", "Convention on Biological Diversity", and "Science for the Twenty-first Century: A New Commitment". All standards can help nations formulate programs in indigenous education. The principles have been incorporated in International Labor Organization Convention 169, in the Indigenous. If the government refers to policies and projects put forward by international organizations regarding indigenous people, it will be helpful for indigenous people in every country to think about and bring in the practice of reviving and promoting indigenous culture (Battiste, 2005).

The enhancement of international education boosts the culture and cultural competence of indigenous students. As promoting international education and students' multiple horizons is related to international competitiveness, it is necessary to ensure that this promotion extends to indigenous schools.

Taiwan's aboriginal population accounts for approximately $2 \%$ of the entire population, with 16 tribes being officially recognized (Council of Indigenous Peoples, 2014). Affected by the international movement, Taiwan has implemented multicultural policies over the past 10+ years. For example, in 2005, Taiwan's government 
enacted the Aboriginal Basic Law to ensure indigenes' civil rights and lay the foundation for development and promotion of aboriginal policy to ensure their sustainability.

In 2011, "A White Paper on International Education" and "A White Paper on Indigenous Educational Policy" were published by the Ministry of Education (MOE) to address educational programs in terms of policy, systems, and plans for indigenous education. Whereas "A White Paper on International Education" sought to expand elementary and high school students' international horizons and cultivate their competitiveness, "A White Paper on Indigenous Educational Policy" asserted that the main task in boosting indigenous peoples is to train them for specialized employment (Ministry of Education, 2011a, 2011b). To ensure equal civil rights, the government has provided significant funding to establish a preferential quota in higher education and enable the aborigines to engage in international educational exchange activities. The latter white paper also emphasized localization to conserve and spread indigenous culture and education. In the era of globalization, it is imperative for children to learn how to locate themselves (Parmenter, Lam, Seto, \& Tomita, 2000). However, a dilemma emerged for indigenous schools in the simultaneous implementation of internationalization and localization. Will the pursuit of internationalization hinder the implementation of localization with limited time and human resources? Or, will internationalization and localization generate better results through a combined implementation? Localization is still a basic requirement for schools that try to internationalize; this must be taken into account.

International education is related to indigenous students' competitiveness even to achieve social justice. Through international education, disadvantaged students' competitiveness can be strengthened. As a result, it is important to understand how international education is promoted in the indigenous schools and what aspects are emphasized for students, schools, tribes, and society.

As school principals are responsible for policy execution, what they focus on will influence the internationalized consequences and ethnic locational development. Thus, this study will explore principals' values regarding international education and the important issues they have defined. To allow for practical applications, the effective and ineffective items will be ordered by the indigenous school principals. Finally, this study will present the goals of and strategies for international education that these principals have considered and identify the corresponding approach to achieve the desired results.

\section{Literature Review}

\subsection{Internationalization in Taiwan's Elementary Schools}

Internationalization and globalization are related but distinct concepts. Globalization is the catalyzer; internationalization is the proactive reply. A country's response to and relationships with other countries is shaped by its history, indigenous culture, and resources. The notion of nation and cultural identity is the main element of internationalization. The homogenization of culture is frequently quoted as a key concern of globalization while internationalization respects or even strengthens local and national culture (Knight, 1997).

Knight put forward four approaches to internationalize at the institutional level: activity approach, competency approach, ethos approach, and process approach. The activity approach involves international curriculums, student/faculty exchanges, technical assistance, and international students. This approach is the basic or beginning step in elementary school, since elementary school is the initial stage of education. Thus, curriculum and student/faculty exchanges are two common activities in elementary school education. In the 1970s and early 1980s, the activity approach and international education were seen as having the same meaning (Knight, 1997).

Influenced by technological development and global interactions, countries and societies are strongly related to a global system (Held \& McGraw, 2003). Globalization increases the urgency of international education; thus, many countries have decided to proceed from higher education (Knight \& de Wit, 1995; Knight \& de Wit, 1999; OECD, 2009). Internationalization of higher education is one of the ways countries both respond to the effects of globalization and respect the particularity of nations. This concept can also be applied to elementary schools' internationalization (Knight, 1997). Indeed, many countries, including Taiwan, have already implemented international education in the lower grades in schools (Lin \& Chen, 2013).

Elementary education in Taiwan is compulsory for children for six years. Taiwan has realized the significance of global connections and carried out further curriculum reform. In the Grade 1-9 Curriculum Guidelines, the government categorized "cultural learning and international understanding" into 10 basic abilities. The curriculum planned for first grade to sixth grade focused on international understanding competency. In addition, from third grade, every school child takes English class as a required course (Ministry of Education, 2001).

The general definition of education internationalization is the process of diversification and internationalization merged into education, research, and service (Knight \& de Wit, 1995), and the implementation of educational 
internationalization can be divided into four aspects: teachers' and students' transnational moving, internationalization of courses, research contacts between countries and open learning projects, and educational certification between nations bilaterally and regionally (Harman, 2004). Because of "A White Paper on International Education," Taiwan engages in international education in four respects: development and teaching of curriculum, international exchanges, teachers' professional development, and school internationalization to broaden students' global vision (Ministry of Education, 2011).

\subsection{Importance of Promoting International Education in Indigenous Elementary Schools}

In the era of globalization, it is imperative for children to learn how to locate themselves (Parmenter, Lam, Seto, \& Tomita, 2000). By participating in international activities, indigenous people can achieve the objective to, as Stefano Varese said, "think locally, act globally" (NACLA, 1991). International relations and transnational alliances play a determining role in the domestic social change of indigenous people. Brysk (1996) argued that transnational alliances have reached beyond state boundaries, thereby improving indigenous people's social situation and increasing their opportunities to participate in politics. When indigenous people worldwide introduce indigenous culture into educational systems using a holistic and appropriate approach, not only indigenous people but also non-indigenous people, educators and students, will benefit (Brady, 1997).

Taiwan's aboriginal population is more than 500,000. Aboriginal students number about 45,000, accounting for $3.5 \%$ of elementary school students in general (Census and Statistics Department of MOE, 2014). Most indigenous students live in tribes with their parents, but some move to a metropolis for study. The aboriginal schools in this study are based on the definition in article 3 of the Aboriginal Education Act Enforcement Rules. Aboriginal students make up a certain number or proportion of elementary school students. In aboriginal areas, aboriginal students make up more than a third of the total number of students; in non-aboriginal areas, the number of aboriginal students is frequently up to a hundred, also more than a third of the total number of students.

Taiwan's indigenous schools promote international education by following "The International Education White Paper," which was implemented by both elementary and high schools in Taiwan. Given the different ethnic groups, the paper stressed that the goals for the students, schools, ethnicities, and society also differ. To date, no relevant survey on this issue has been conducted. Nevertheless, exploring the significance of promoting international education increases its effectiveness. For indigenous schools, the importance of international education can be determined from the effect of the goals for students, schools, ethnicities, and society, as discussed in the following paragraphs.

In terms of students' goals, international education promotes indigenous students' international visions and improves their foreign language skills, including English, an international language. For non-English-speaking countries, teaching English at the primary stage is very important (Dronker, 1993). However, the number of Chinese speakers is growing, so the US and UK are teaching Chinese as well as other languages (Howe, 2008). Taiwan's revised Grade 1-9 Curriculum Guidelines require students to study English from third grade in elementary school (starting in 2011), thereby indicating that promoting students' English ability and broadening their horizons are priorities.

In terms of schools' goals, international education promotes the indigenous school enrollment and access to government and private organization grants. Because of Taiwan's implementation of international education, the elementary and high schools must submit projects to obtain MOE funding. Qualified schools receive an allowance from the government or private agencies to help the schools carry out specific programs and then, it is hoped, improve the recruitment of students. In recent years, Taiwan's low birth rate has decreased enrollment. Only schools with meaningful characteristics will attract students in the future.

In terms of ethnic goals, international education promotes indigenous students' knowledge and traditional cultural wisdom, as well as boosts their awareness of ethnicities. Globalization drives international exchange and cooperation and opens up new opportunities, but it might create obstacles for indigenous peoples to preserve their culture and local wisdom (Moahi, 2007). Indigenous academics promote such knowledge by displaying the richness of indigenous languages, worldviews, teachings, and experiences, while contemporary educational institutions and Eurocentric knowledge systems exclude all such information (Battiste, 2005). International policy is established to protect indigenous knowledge from the pillage of biopiracy (Shive, 1997; Gollin, 1999; Battiste, 2005). Indigenous knowledge and its pedagogies have generated a decolonizing and rethinking of education for indigenous peoples (Mcconaghy, 2000; Battiste, 2005). Therefore, understanding indigenous wisdom and enhancing ethnic identity are primary objectives when implementing international education. Otherwise, indigenous culture will also be eliminated during international exchange. 
In terms of societal goals, international education can foster a multicultural environment, leading to the development of appreciation and tolerance for different cultures. The current patterns of mainstream education and indigenous education differ based on the research in Western countries. Two patterns are revealed in terms of worldview, epistemology, and pedagogy. Examining the interflow and cooperation in a comparative study among indigenous people would help in understanding the methods of indigenous education (Mundy et al., 2008) and trace the indigenous tradition and culture (McKinley, 2005). By understanding the culture and international perspectives, individuals with similar cultural backgrounds can cherish their shared local cultural resources and understand the commonalities with others. Teachers can also learn how to deal with interpersonal and international cultural differences by helping students develop their cultural identity, build empathy for different cultures, and ultimately expand their international perspective to cultivate global citizens' efforts to pursue justice and peace (Ministry of Education, 2004). Therefore, keeping an open mind to all kinds of cultures is an important purpose of promoting international education for indigenous elementary schools.

Based on the literature reviewed thus far, one can see the importance of policy that includes the promotion of indigenous students' international visions, improvement of indigenous students' foreign language skills, advancement of the competitiveness of school enrollment, access to grants from government or private organizations, indigenous knowledge and traditional cultural wisdom, awareness of ethnicities, establishment of a multicultural environment, and an appreciation and tolerance for different cultures. These are all attributed to students, schools, ethnicities, and society at the secondary level.

\subsection{Strategy of International Education in Indigenous Primary Implementation}

In Taiwan, the internationalization of elementary and high school education has mainly followed "The International Education White Paper" to implement four aspects: curriculum development, teaching, international exchanges, and teachers' professional development (Ministry of Education, 2011). Taiwan is a non-English-speaking country, so introducing English at the primary level was deemed to be critical for internationalization (Dronker, 1993).

On the other hand, people in English-speaking countries are supporting the learning of Chinese and other languages. For example, in Ohio in America, internationalization has been executed by hiring Arabic, Chinese, Japanese, Spanish, and French native speakers to teach language courses. In addition to the establishment of the International Advisory Board of Education, which set out to promote policies and laws throughout the state to encourage and establish global education, state authorities support the exchange of teachers into various regions to carry out experimental programs and educational training and also hold international education summits to emphasize the importance of such education for citizens (Howe, 2008).

Influenced by internationalization, the strategies for implementation of international education are broadly similar in every country. For example, international partners and sister schools help promote collaborative research by expanding the exchange of faculty and students. In addition, curriculum enrichment and student recruitment (Kirk \& MacDonald, 2001), fundraising, meetings, and overseas resource-sharing are common ways to promote the internationalization of education (Vidovich, 2004; Fortuijn, 2002; Zheng et al., 2001). Students' learning experiences should incorporate internationalization, technology improvements, school visits, practical training, and service learning all combined with the use of technology (Asia Society, 2008). Indigenous students will be empowered if indigenous knowledge, heritage, and languages are integrated into the national educational system (Battiste, 2005). These are common implementation strategies for international education to develop global partnerships.

Most indigenous elementary schools are located in remote geographic areas where international volunteers are involved. In this case, there are more opportunities for international exchanges (World Volunteer Web, 2014), allowing foreign volunteers to devote themselves to the implementation of international indigenous elementary education.

As the literature indicates, the promotion of international education for indigenous students includes actively recruiting foreign students, encouraging staffs to participate in a variety of international studies, constructing the learning environment of foreign languages, integrating international knowledge into the curriculum, establishing partnerships with foreign schools, conducting study abroad and overseas visiting programs, promoting long-distance exchanges of domestic and international students, participating in various international competitions, and dealing with community foreign volunteers. The current study will focus on the effectiveness of these activities and the purposes of the different strategies to provide additional information about international education efforts. 


\section{Methodology}

\subsection{Analytic Hierarchy Process}

Saaty (1980) proposed the analytic hierarchy process (AHP) to allow respondents to make comparisons and select the most important factors. Difficulties existed because it involves limited information and people's restricted reasoning ability so that individuals cannot identify the importance of what is mentioned in the research in a limited time. The correlations between the importance of each factor is also not easy to determine. However, AHP can serve as a guideline for a rating scheme based on a comparison of mutual importance, given different levels of value, through operation to determine the ultimate reference value (Saaty, 1980).

When overall goals are identified, the sub-objectives should be listed as the impact of the characteristics of the secondary objectives (attributes); as a result, multiple levels are formed. In pairwise comparisons, it is easier to assess the correlations between the importance of each factor. Finally, the regular reciprocal matrix formula is used to calculate relative importance. The formula is shown in Figure 1.

$$
\begin{aligned}
& \mathrm{A}=\left[\mathrm{a}_{\mathrm{ij}}\right]\left[\begin{array}{cccc}
1 & a_{12} & & a_{1 m} \\
a_{21} & 1 & \cdots & a_{2 m} \\
& \vdots & \ddots & \vdots \\
a_{m 1} & a_{m 2} & \cdots & 1
\end{array}\right]
\end{aligned}
$$

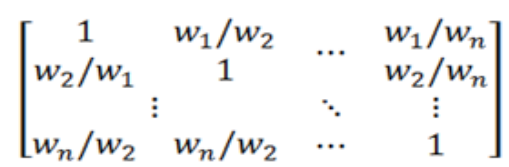

$$
\begin{aligned}
& \text { The weight is: } \mathrm{Wi}=1 / \mathrm{m} \quad \sum_{j=1}^{m} \frac{a_{i j}}{\sum_{k=1}^{m} a_{k j}}
\end{aligned}
$$

Figure 1. Formula to calculate weights

Note: "aij" stands for "row i" and "column j" represents the positive reciprocal matrix; "akj" stands for a normalized "row k."

The value of pairwise comparison matrices is based on the questionnaire respondent's subjective judgments, and the determined level and factors are numerous; thus, maintaining consistency is more difficult in the assessment of pairwise comparisons. Given the need for consistency in the numerical test, the consistency index (CI) is used to examine the respondents' answers comprising the comparison matrix. If the degree of consistency in the hierarchy does not meet the requirements, the levels of associated elements will be affected and must be re-checked. The formula shown in Figure 2 is often used, where $\lambda$ max is employed to confirm the consistency of handling respondents' content. If Consistency Ratio $(\mathrm{CR})<0.1$, then it is considered a pass.

$$
\begin{aligned}
& \mathrm{A} \times \mathrm{K}-\left[\begin{array}{cccc}
1 & a_{12} & \ldots & a_{1 m} \\
a_{21} & 1 & & a_{2 m} \\
& \vdots & \ddots & \vdots \\
a_{m 1} & a_{m 2} & \cdots & 1
\end{array}\right] \times\left[\begin{array}{c}
w_{1} \\
w_{2} \\
\vdots \\
w_{m}
\end{array}\right]-\left[\begin{array}{c}
w_{1}^{t} \\
w_{1} \\
\vdots \\
\vdots \\
w_{m}^{\prime}
\end{array}\right] \\
& \lambda_{\max }-(1 / \mathrm{m}) \times\left(\frac{\mathrm{w}_{1}^{\prime}}{\mathrm{w}_{1}}+\frac{\mathrm{w}_{2}}{\mathrm{w}_{2}}+\cdots+\frac{\mathrm{w}_{m}^{\prime}}{\mathrm{w}_{m}}\right) \\
& \mathrm{CI}=\frac{\lambda \max -m}{m-1} \quad \mathrm{CR}=\frac{C I}{R I}
\end{aligned}
$$

Figure 2. Consistency test formula

\subsection{AHP Structure}

Figure 3 shows the complete framework based on the literature review. The indigenous elementary schools' international education goals belong to the first dimension, located on the far left. The second dimension 
comprises four goals (student, institution, ethnicity, and society), forming the effectiveness of the overall objectives. The third dimension is composed of indigenous elementary schools' eight international education features.

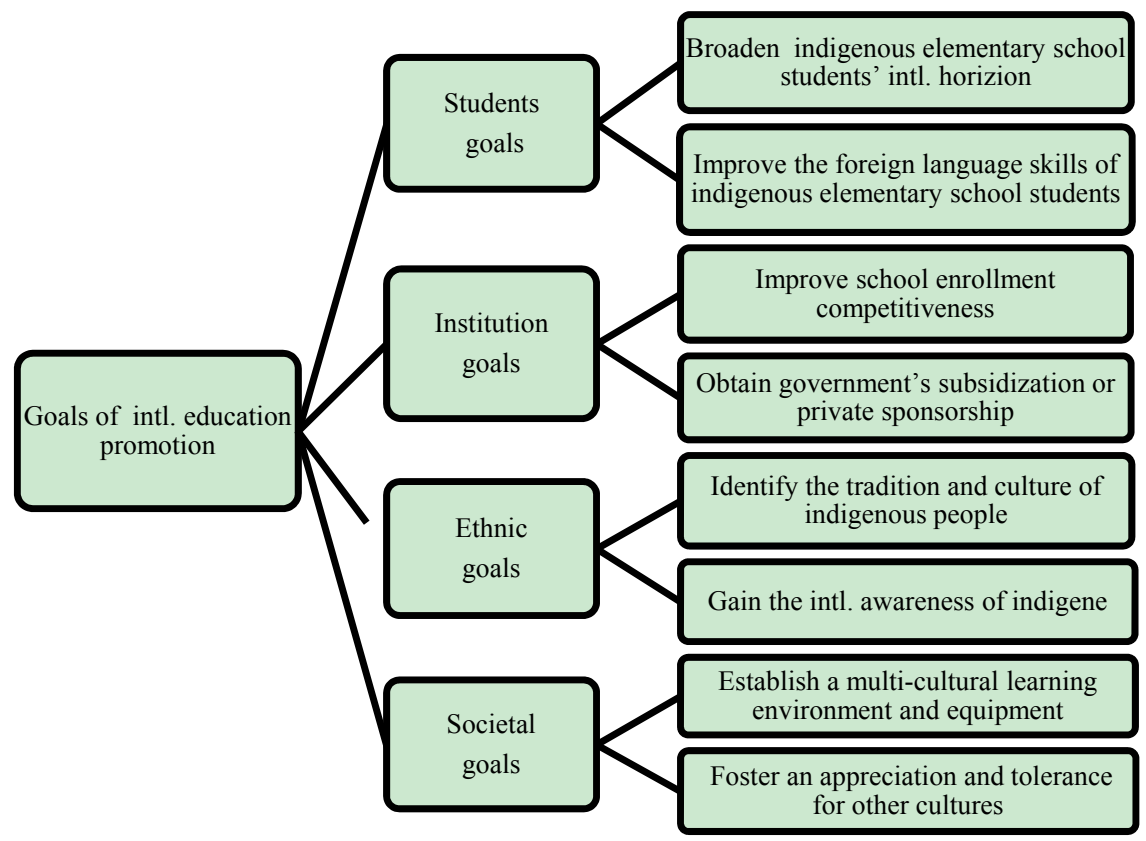

Figure 3. Goals for promoting international education

\subsection{Design of the Questionnaire}

This questionnaire was researcher-created. It was designed after the literature review and a full discussion with five experts. The questionnaire was divided into three parts. The first gathered background information from respondents. The second part, completed by indigenous elementary school principals, determined the weight placed on the goals of promoting international education at the student, institution, ethnicity, and societal levels, which includes eight items (see Figure 3). The third part included a cross-table of 8 objectives and 10 methods to identify the strategies for promoting international education.

\subsection{Participants}

Questionnaires were sent to 150 elementary principals, and the response rate was $51.3 \%$. Males accounted for $79 \%$ of responses, compared to $21 \%$ for females; $70.3 \%$ of principals in indigenous schools are non-indigenes and $29.7 \%$ are indigenes.

\section{Research Results}

AHP was adopted to calculate the weight of the dimensions (the second dimension) and the sub-goals of promoting indigenous elementary schools (the third dimension). The CR value is $0.002(<0.1)$, which corresponds to the consistency test that Saaty (1980) suggested. The principals see each level of international education as carrying varying degrees of importance. The student dimension (0.48) is the most important for the principals, followed by the ethnic dimension $(0.21)$, the society dimension $(0.19)$, and the institution dimension (0.12); see Table 1.

Table 1. Principals' weights of the three dimensions

\begin{tabular}{ccccc}
\hline First Dimension & CR & Second Dimension & Weight & Order \\
\hline \multirow{2}{*}{ Goals } & 0.002 & Student & 0.48 & $(1)$ \\
& $(<0.1)$ & Ethnicity & 0.21 & $(2)$ \\
& & Society & 0.19 & $(3)$ \\
& & Institution & 0.12 & $(4)$ \\
\hline
\end{tabular}


As Table 2 indicates, the weighted results of the third dimension show that broadening the international horizon (A) was the most important goal (0.33), followed by improving foreign language skills (B) (0.15) and identifying tradition and culture (E) (0.14). The three least important goals of international education are to obtain subsidization or sponsorship (D) (0.05), gain international awareness (F) (0.06), and improve enrollment competitiveness (C) (0.07).

Table 2. Weights of main goal and third-dimension attributes

\begin{tabular}{|c|c|c|c|c|c|}
\hline $\begin{array}{c}\text { First } \\
\text { dimension }\end{array}$ & $\begin{array}{c}\text { Second } \\
\text { dimension }\end{array}$ & Third dimension & $\begin{array}{l}\text { Raw } \\
\text { Score }\end{array}$ & $\begin{array}{l}\text { Weighted } \\
\text { Score }\end{array}$ & Rank \\
\hline \multirow{8}{*}{ Goals } & Students' & broaden international horizon (A) & 0.67 & 0.33 & (1) \\
\hline & goals & improve foreign language skills (B) & 0.33 & 0.15 & (2) \\
\hline & Ethnic & identify tradition and culture $(\mathrm{E})$ & 0.60 & 0.14 & (3) \\
\hline & goals & gain international awareness $(\mathrm{F})$ & 0.40 & 0.06 & (7) \\
\hline & Society & $\begin{array}{c}\text { establish a multicultural learning } \\
\text { environment }(\mathrm{G})\end{array}$ & 0.53 & 0.08 & $(5)$ \\
\hline & goals & $\begin{array}{l}\text { foster appreciation for other cultures } \\
\qquad(\mathrm{H})\end{array}$ & 0.47 & 0.12 & (4) \\
\hline & \multirow[t]{2}{*}{ Institution goals } & $\begin{array}{l}\text { improve enrollment competitiveness } \\
\text { (C) }\end{array}$ & 0.65 & 0.07 & (6) \\
\hline & & obtain subsidization or sponsorship (D) & 0.35 & 0.05 & (8) \\
\hline
\end{tabular}

Furthermore, the author investigated the implementation level of the international activities. Table 3 shows that the enhanced performance of each international education activity implemented, as perceived by the indigenous elementary school principals, was ranked as follows: integrate international knowledge into the curriculum (3.29), provide foreign language courses and related cultural curriculum (3.17), and achieve a school-wide foreign language learning environment (3.05). Only these three items are above the mean; that is, most of the international activities are not carried out well. The principals ranked three items lowest: actively recruit foreign students (1.58), hold frequent overseas study tours or visits (1.80), and establish partnerships with international schools (1.87).

Table 3. Principals' perceptions of indigenous international activities

\begin{tabular}{|c|c|c|c|}
\hline Indigenous international activities items list & Mean & Rank & STD \\
\hline integrate international knowledge into the curriculum (4) & 3.29 & 1 & 0.92 \\
\hline provide foreign language courses and related cultural curriculum (10) & 3.17 & 2 & 1.22 \\
\hline achieve a school-wide foreign language learning environment (3) & 3.05 & 3 & 1.07 \\
\hline encourage staff to attend international education workshops (2) & 2.57 & 4 & 1.01 \\
\hline hold overseas volunteer activities for students (9) & 2.30 & 5 & 1.39 \\
\hline encourage domestic and international school exchanges (7) & 2.07 & 6 & 1.14 \\
\hline join a variety of international competitions (8) & 1.89 & 7 & 0.95 \\
\hline establish partnerships with international schools (5) & 1.87 & 8 & 1.14 \\
\hline hold frequent overseas study tours or visits (6) & 1.80 & 9 & 0.99 \\
\hline actively recruit foreign students (1) & 1.58 & 10 & 0.77 \\
\hline Average & 2.36 & & \\
\hline
\end{tabular}

Finally, the researcher adopted correspondence analysis (CA) to create a map displaying the relative positioning of the implementation types (Figure 4). The X2 of 142.4 and the CR value of .000 indicate that the perceptual map created by $\mathrm{CA}$ was feasible. There are three types of correspondences:

1. (E), (H), and (1), (4): For schools, both actively recruiting foreign students (1) and integrating international knowledge into the curriculum (4) will help effectively achieve identifying with the tradition and culture of indigenous people $(\mathrm{E})$ and fostering an appreciation and tolerance for other cultures $(\mathrm{H})$. 
2. (A) and (6), (7), (9): Schools that hold frequent overseas study tours or visits (6), encourage domestic and international school exchanges (7), and hold overseas volunteer activities for students (9) will help broaden indigenous elementary school students' international horizons (A).

3. (B), (G) and (2), (10): Schools that encourage staff to attend international education workshops (2) and provide foreign language courses and related cultural curriculum (10) will help improve the foreign language skills of indigenous elementary school students (B) and establish a multicultural learning environment (G).

These three types of correspondences can provide information when internationalization policies are implemented in domestic indigenes' elementary schools, enabling these schools to consider more effective activities.

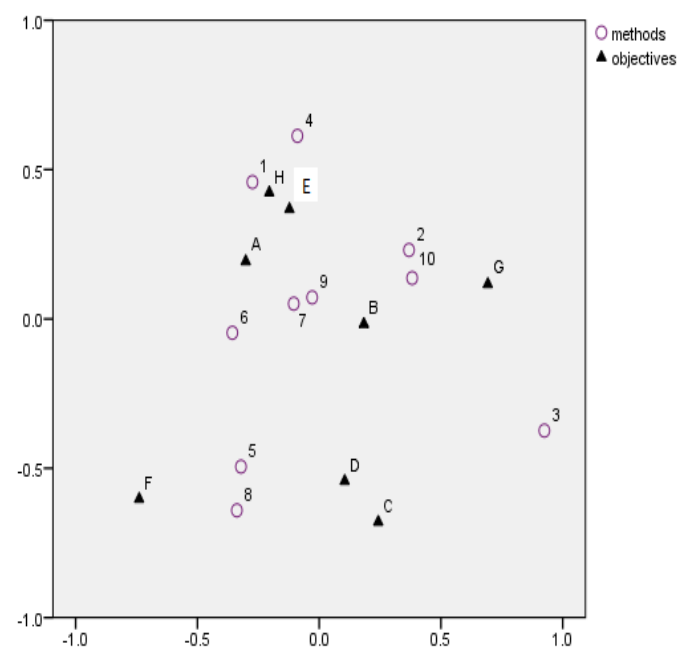

Figure 4. Correspondence between international goals and methods in indigenous elementary schools

Note: (A) broaden international horizon; (B) improve foreign language skills; (C) improve enrollment competitiveness; (D) obtain subsidization or sponsorship; (E) identify tradition and culture; (F) gain international awareness; $(\mathrm{G})$ establish a multicultural learning environment; $(\mathrm{H})$ foster appreciation for other cultures; (1) recruit foreign students; (2) attend international workshops; (3) provide foreign language environment; (4) integrate international knowledge into curriculum; (5) establish partnerships; (6) engage in overseas study or visits; (7) provide international school exchanges; (8) join international competitions; (9) volunteer overseas; (10) offer foreign language courses and cultural curriculum

\section{Conclusion and Discussion}

This research sought to identify the main reasons for promoting educational internationalization based on information gathered from indigenous schools' principals via questionnaires. Calculating the proportion of responses helped determine the order of criteria that schools emphasize to enhance the educational internationalization policy.

1. The analysis indicated that indigenous elementary schools' principals consider the students to be the first beneficiary of such education, followed by the ethnic groups, the institute, and the society.

In Lin and Chen's (2013) research, Taiwan's non-indigenous elementary schools' principals ranked such dimensions in the same order. Principals in every school considered that the students should be the primary beneficiary. As compared with Japanese principals, they emphasized the institute rather than students. This difference might stem from the international education system that Taiwan is pushing forward. In addition, Japan's promotion of international education occurred earlier and had already put emphasis on curriculum; as a result, the expense in other aspects was limited.

2. In the process of promoting educational internationalization, indigenous elementary schools in Taiwan emphasize, first, broadening international horizons, second, improving foreign language skills, and, third, identifying tradition and culture.

The first two goals are attributed to the students' dimension, as discussed in the previous paragraph, whether an indigenous school or not; Taiwan implemented an international education emphasis for gains at the student level. 
The third goal for indigenous school principals involves ethnic groups. In the process of implementing indigenous elementary international education, cultural exchanges with schools in other countries occur through exhibitions and sharing based on ethnic culture. Thus, it is easy to realize the importance of maintaining traditional ethnic cultures and stimulating attention to ethnic cultures.

3. The least important issues emerging when indigenous elementary schools promote international education are obtaining subsidization or sponsorship, which might stem from sufficient educational sponsorship from the government, gaining international awareness, which might be related to Taiwan's indigenous regions, and improving enrollment competitiveness; in contrast, ethnic consciousness is more urgent than international awareness. Despite the low birth rate affecting indigenous regions, the principals seem not to believe that promoting international education has been sufficiently effective.

4. Generally speaking, indigenous elementary school principals do not think international activities have been effective in the schools.

Even so, more successful projects have been conducted, such as integrating international knowledge into the curriculum, providing foreign language courses and related cultural curriculum, and achieving a school-wide foreign language learning environment. These projects are related to course design and the shaping of the teaching environment. Finally, some projects have been less than ideal, such as actively recruiting foreign students, which requires family cooperation, holding frequent overseas study tours or visits, for most indigenous families are economically disadvantaged, and establishing partnerships with international schools, which requires extensive efforts by schools to establish partnerships and achieve specific goals.

5. This research found three corresponding relationships: The implementation of various international education programs can achieve its goal using different strategies.

To promote smooth international education, indigenous elementary schools should focus on the original purpose of internationalization by choosing the most effective implementation strategies. Comparatively raising international awareness might involve proposing additional efficient approaches that incorporate the issue of ethnic consciousness.

\section{Implications}

The results of this study reflect less success in indigenous elementary schools than in non-indigenous elementary schools in encouraging staff to attend international education workshops (Lin \& Chen, 2013). In the indigenous elementary schools, encouraging staff to attend international education workshops has not been at all effective. As schools advocate international education, the teacher is the key factor. If the government wants such education to be more effective, indigenous schools must hold more learning activities. Therefore, this research suggests that the government should encourage indigenous elementary school staffs to participate in various kinds of international learning activities.

During the process of promoting international cooperation and exchange, new opportunities arise from globalization, but these opportunities might also create obstacles to preserving indigenous culture and knowledge (Cesarotti, 2009; Smith \& Ward, 2000). Adopting both traditional culture and international education are important for indigenous students, but recognizing internationalization as the only means of public schooling will damage indigenous knowledge, culture, beliefs, and ways of life (Battiste, 2005). Therefore, determining how to help students in such circumstances maintain their ethnic culture and flourish is a significant issue for Taiwan and the world's indigenes.

\section{References}

Asia Society. (2008). Going global: Preparing our students for an interconnected world. New York: The council of chief state school officers. Retrieved from http://AsiaSociety.org/Education

Battiste, M. (2005). Indigenous knowledge: Foundations for First Nations. Retrieved from http://142.25.103.249/integratedplanning/documents/IndegenousKnowledgePaperbyMarieBattistecopy.pdf

Brady, W. (1997). Indigenous Australian education and globalisation. International Review of Education, 43(5-6), 413-422.

Brysk, A. (1996). Turning weakness into strength: The internationalization of Indian rights. Latin American Perspectives, 23(2), 38-57.

Census and Statistics Department of MOE. (2014). 2013 Indigenous students' summary in Taiwan. Retrieved from https://stats.moe.gov.tw/files/analysis/102native.pdf 
Cesarotti, B. (2009). Globalization's impact on indigenous peoples in Mexico and Bolivia. Retrieved from http://smashthemirror.files.wordpress.com/2009/05/globalization-and-indigenous-peoples.pdf

Dronkers, J. (1993). The causes of growth of English education in the Netherlands: Class or internationalization? European Journal of Education, 28(3), 295-307.http://dx.doi.org/10.2307/1503760

Fortuijn, J. D. (2002). Internationalising learning and teaching: A European experience. Journal of Geography in Higher Education, 26(3), 263-273. http://dx.doi.org/10.1080/0309826022000019855

Harman, G. (2004). New directions in internationalization higher education: Australia's development as an exporter of higher education services. Higher Education Policy, 17, 101-120. http://dx.doi.org/10.1057/ palgrave.hep. 8300044

Held, D., \& McGraw, A. (2003). The global transformations reader: An introduction to the globalization debate (2nd ed.). Cambridge, UK: Polity.

Howe, D. (2008). Schools without walls. Phi Delta Kappan, 90(3), 206-210.

Kirk, D., \& MacDonald, D. (2001). Teacher voice and ownership of curriculum change. Journal of Curriculum Studies, 33(5), 551-567.

Knight, J. (1997). Internationalization of higher education: A conceptual framework. In J. Knight, \& H. De Wit (Eds.) Internationalization of higher education in Asia Pacific countries (pp. 5-19). Amsterdam: European Association for International Education.

Knight, J. (2003). Updating the definition of internationalization. International Higher Education, 33, 2-3.

Knight, J., \& de Wit, H. (1995). Strategies for internationalization of higher education: Historical and conceptual perspectives. In H. de Wit (Ed.), Strategies for internationalization of higher education (pp. 5-32). Amsterdam: EAIE.

Knight, J., \& de Wit, H. (Eds.). (1999). Quality and internationalization in higher education. Paris: OECD Publications.

Lin, M., \& Chen, S. (2013). A Comparison of the Internationalization of Education in Taiwan and Japan: The Perspective of Elementary School Principals. International Education Studies, 7(1), 47-59. http://dx.doi.org/10.5539/ies.v7n1p47

McConaghy, C. (2000). Rethinking indigenous education: Culturalism, colonialism and the politics of knowing. Flaxton, Queensland: Post Pressed.

McKinley, E. (2005). Locating the global: culture, language and science education for indigenous students. International Journal of Science Education, 27(2), 227-241. http://dx.doi.org/10.1080/0950069042000325 861

Ministry of Education. (2001). Grade 1-9 curriculum guidelines. Taipei: MOE.

Ministry of Education. (2004). 2005-to-2008 education policy principles. Taipei: MOE.

Ministry of Education. (2011a). A white paper on international education for primary \& secondary schools. Taipei: MOE.

Ministry of Education. (2011b). A white paper on indigenous educational policy. Taipei: MOE.

Moahi, K. H. (2007). Globalization, knowledge economy and the implication for indigenous knowledge. International Review of Information Ethics, 7, 1-8.

Mundy, K. Bickmore, K., Hayhoe, R., Madden, N., \& Madjidi, K. (Eds.). (2008). Comparative and international education: Issues for teachers. Toronto: Canadian Scholars Press, Inc.

OECD. (2009). Higher education to 2030 (Vol. 2: Globalization). Paris: Centre for Educational Research and Innovation, OECD.

Parmenter, L., Lam, C., Seto, F., \& Tomita, Y. (2000). Locating self in the world: elementary school children in Japan, Macau and HongKong. Compare: A Journal of Comparative and International Education, 30(2), 133-144. http://dx.doi.org/ DOI: 10.1080/03057920050034084

Rivera Cusicanqui, S. (1991). Aymara past, Aymara future. NACLA, Report on the Americas: The First Nation, 1492-1992, 25(3), 18-23.

Saaty, T. L. (1980). Analytic hierarchy process: Planning, priority, setting, resource allocation. New York: McGraw-Hill. 
Shiva, V. (1997). Biopiracy: The plunder of nature and knowledge. Cambridge, Mass.: South End Press.

Smith, C., \& Ward, G. (2000). Indigenous cultures in an interconnected world. Vancouver: UBC Press.

UNESCO. (2014). Culture. Retrieved from http://portal.unesco.org/culture/en/ev.php-URL_ID=35393\& URL_DO=DO_TOPIC\&URL_SECTION $=201 . \mathrm{html}$

Vidovich, L. (2004). Towards internationalizing the curriculum in a context of globalization: comparing policy processes in two settings. Compare: A Journal of Comparative and International Education, 34(4), 443-461. http://dx.doi.org/10.1080/0305792042000294823

World Volunteer Web. (2014). Volunteerism worldwide: News, views \& resources. Retrieved from http://www.worldvolunteerweb.org/iyv-10/stakeholders/ngos.html

Zheng, X. X., Hinshaw, A. S., Yu, M. Y., Guo, G. F., \& Oakley, D. J. (2001). Building international partnerships. International Nursing Review, 48, 117-121. http://dx.doi.org/10.1046/j.1466-7657.2001.00058.x

\section{Copyrights}

Copyright for this article is retained by the author(s), with first publication rights granted to the journal.

This is an open-access article distributed under the terms and conditions of the Creative Commons Attribution license (http://creativecommons.org/licenses/by/3.0/). 